\title{
First Report of Cucumber mosaic virus Infecting Siam Tulip (Curcuma alismatifolia) in Florida
}

\author{
K. K. Dey, ${ }^{1,+}$ C. Li, ${ }^{1}$ M. Elliott, ${ }^{2}{ }^{3}$ ohn McVay, ${ }^{1}$ L. Whilby, $^{1}$ G. Hodges, ${ }^{1}$ and T. R. Smith ${ }^{1}$ \\ ${ }^{1}$ Florida Department of Agriculture and Consumer Services, Division of Plant Industry, Gainesville, FL 32614 \\ ${ }^{2}$ University of Florida, Gainesville, FL 32614
}

Accepted for publication 31 May 2019.

Keywords: Cucumber mosaic virus, cucumovirus, Bromoviridae, Curcuma alismatifolia, Siam tulip

Siam tulip (Curcuma alismatifolia) is a tropical perennial plant native to Laos, northern Thailand, and Cambodia. It grows from rhizomes and is a member of the large ginger family (Zingiberaceae Martinov). C. alismatifolia has gray-green foliage reaching 3 to 4 feet in height. Cut flowers and tubers of $C$. alismatifolia are exported to many countries, including Japan, the United States, the Netherlands, and New Zealand (Pubuwpern 1992). It has become an important crop for breeding new varieties owing to its high economic value as a tropical ornamental (Prathepha 2000). In September 2017, four C. alismatifolia potted plants, growing in Alachua, FL, were submitted to Florida Department of Agriculture and Consumer Services, Division of Plant Industry, Gainesville, FL, for pathogen identification. The plants exhibited petal and bract necrosis (Figs. 1 and 2). Initial serological testing for the presence of cucumber mosaic virus (CMV) using lateral flow assays and antigen-coated plate ELISA (Agdia, Elkhart, IN) yielded positive results in all four plants. To confirm pathogen identification, total RNA was extracted from the bract and petal tissue of four symptomatic plants using an RNeasy Plant Mini kit (Qiagen, Hilden, Germany). All tissues yielded positive results in a twostep quantitative reverse transcription PCR, using primers targeting CMV-specific coat protein (amplicon of $~ 450$ bp) (Wylie et al. 1993). The PCR product was directly sequenced in both directions (GenBank accession MG652768). A BLAST search against the GenBank database indicated the submitted sequences had $99 \%$ nucleotide identity with CMV isolates (GenBank accession nos. AF547217.1, AB004781.1, LC066449.1, KC527751.1, GU327365.1, and AF172842.1). CMV is known to infect a wide variety of plants in the ginger family, but to our knowledge, this is the first report of CMV in Curcuma alismatifolia.

${ }^{\dagger}$ Corresponding author: K. K. Dey; E-mail: kishore.dey@freshfromflorida.com

Funding: This work was funded by the Florida Department of Agriculture and Consumer Services.

The author(s) declare no conflict of interest.

(C) 2019 The American Phytopathological Society

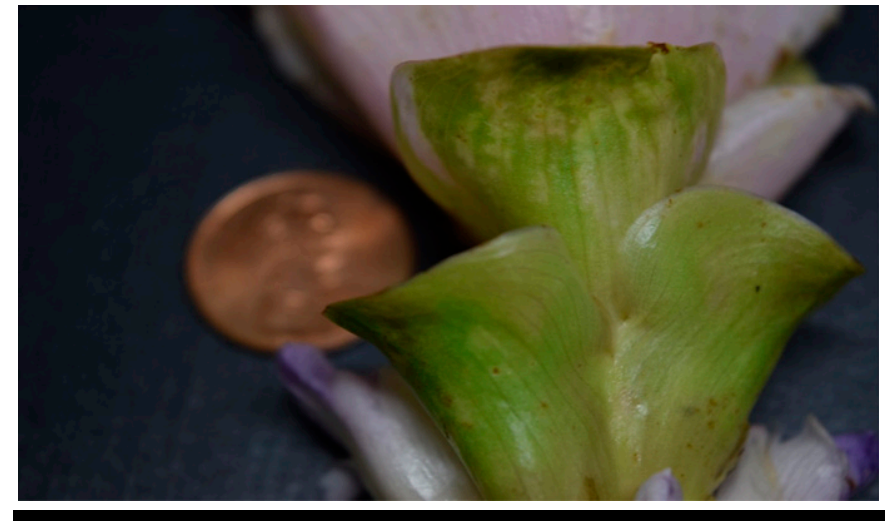

FIGURE 1

Symptom of necrosis on the bract of Curcuma alismatifolia.

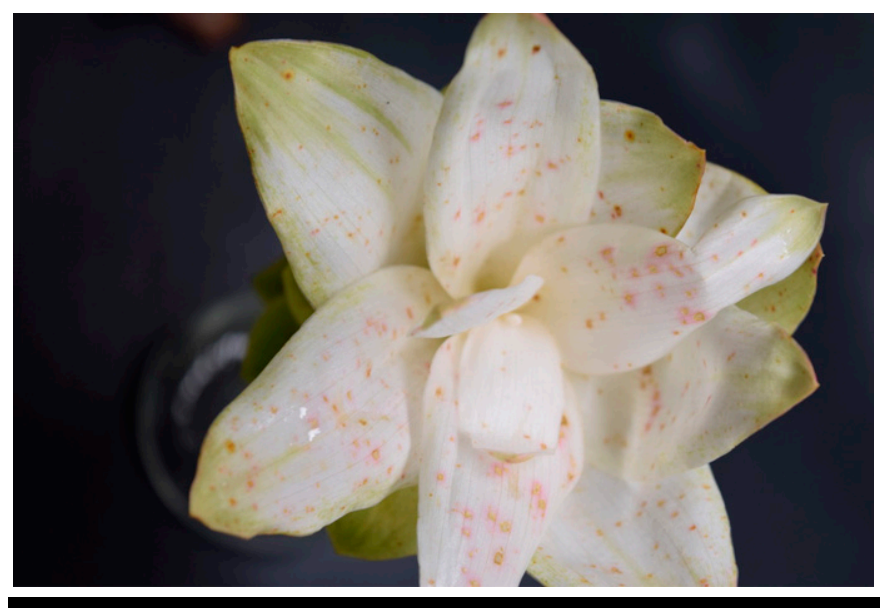

FIGURE 2

Symptom of necrosis on the petals of Curcuma alismatifolia.

\section{Literature Cited}

Prathepha, P. 2000. Screening of random primer to evaluate DNA diversity in Thai Curcuma using random amplified polymorphic DNA. Songklanakarin J. Sci. Technol. 22:8-13.

Pubuwpern, J. 1992. The growth and development of Curcuma. M.Sc. thesis. Chiang Mai University, Chiang Mai, Thailand.

Wylie, S., Wilson, C. R., Jones, R. A. C., and Jones, M. G. K. 1993. A polymerase chain reaction assay for cucumber mosaic virus in lupin seeds. Aust. J. Agric. Res. 44:41-51. 